DOI https://doi.org/10.32782/2305-9389/2020.22.05

УДК 94:2-846(47)]:271.2-523.6(477.41)

Чучалін Олександр,

кандидат історичних наук,

дочент кафедри історії Украӥни

Уманського державного педагогічного університету

імені Павла Тичини

\title{
МОНАСТИРІ КИЇВСЬКОЇ ЄПАРХІЇ В УМОВАХ РЕАЛІЗАЦІЇ РАДЯНСЬКОЇ МОДЕЛІ ДЕРЖАВНО-ЦЕРКОВНИХ ВІДНОСИН (1920-1930-ТІ РОКИ)
}

\begin{abstract}
У статті акцентовано увагу на ролі та значенні православних монастирів у формуванні морального здоров'я суспільства. Відродження цих інституцій у незалежній Украйні сприймається як відродження національної ідентичності і національних иінностей, як ознака морального очищення суспільства, антитеза бездуховності та гонитві за матеріальним благополуччям. Сучасні православні монастирі в Україні перетворилися на центри паломництва і туризму, вони не обділені увагою сучасних політиків і діячів культури.

На початку ХХ ст. монастирі Київської єпархії виконували значну господарську та сочіокультурну функцію, перетворилися на потужні релігійно-культурні иентри. Досліджено долю монастирів Київської єпархї у 1920-1930-х роках. 3'ясовано, щцо у цеей період на них випали вкрай важкі випробування. Монастирі і иерковні общини позбавлялися права власності та статусу юридичної особи. Доведено, щзо у період $1919-1921$ рр. закриття монастирів набуло особливо масового характеру, їх спосіб існування та доля насельників кардинально змінилися. Діяльність чернечих общин була спрямована у ией час на пошук можливих шляхів, які б забезпечили їх фізичне існування у сочіалістичній державі. Необхідність налагодження церковного життя в нових умовах змусили Православну церкву шукати нові форми існування своїх інститутів. 3'ясовано, щуо відповідно до чинного законодавства до 1922 р. майже в усіх монастирях Київської єпархї̈ були утворені релігійні громади. У деяких обителях почали функціонувати сільськогосподарські артілі або трудові комуни. Конфіскація ичерковних иінностей, реорганізація та закриття монастирів і храмів відображали політику радянської держави у царині духовної культури того часу. Установлено, щчо радянська влада знайшла способи і методи, за допомогою яких було закриті монастирі і ліквідовано чернецтво як особливу соціальну групу людей в Украӥні.
\end{abstract}

Ключові слова: Київська єпархія, монастирі, чениі, політика радянської влади, конфіскація, закриття.

\section{Chuchalin Oleksandr. Kyiv Eparchy monasteries under the realization of the Soviet model of state-church relations (the 1920s - 1930s)}

The article highlights the role and importance of Orthodox monasteries in shaping the moral health of society. The revival of these institutions in independent Ukraine is seen as the revival of national identity and national values, the sign of moral purification of the society, as well as the antithesis of godlessness and pursuit of material well-being. Modern Orthodox monasteries in Ukraine have become the centres of pilgrimage and tourism. Besides, they attract the attention of modern politicians and cultural figures.

In the early $20^{\text {th }}$ century, Kyiv Eparchy monasteries performed a significant economic and socio-cultural function and became powerful religious and cultural centres. The article studies the fate of Kyiv Eparchy monasteries between the 1920s and the 1930s. It shows that they were facing difficult times. Monasteries and church communities were deprived of property rights and legal personality. The closure of monasteries between 1919 and 1921 became especially widespread, and their way of life and the fate of the inhabitants changed dramatically. The activities of monastic communities at that time were aimed at finding possible ways that would ensure their physical existence in the socialist state. The need to establish church life under the new conditions forced the Orthodox Church to seek new forms of existence of its institutions. According to the current legislation until 1922, religious communities were formed in almost all monasteries of the Kyiv Eparchy. In some monasteries, agricultural cooperatives or labour communes began to function. The confiscation of church property, as well as the reorganization and closure of monasteries and temples, reflected the policy of the Soviet state in the field of spiritual culture of the time. The Soviet authorities managed to find ways and methods to close monasteries and eliminate monasticism as a special social group of people in Ukraine.

Key words: Kyiv eparchy, monasteries, monks, Soviet policy, confiscation, closure.

В умовах сьогодення особливої актуальності набувають дослідження, що розкривають забуті сторінки духовного минулого нації. Кожна людина, народжена на теренах України, часто не віддає собі належне в тому, що постійно стикається з духовною та культурною традицією, сформованою під впливом православ'я. Упродовж тисячоліття Православна церква своїм релігійно-моральним авторитетом і своїми ідеалами здійснювала колосальний вплив на суспільство через приходи, храми і монастирі. 
У незалежній Україні Православна церква продовжує залишатися чи не єдиною соціальною інституцією, авторитет якої постійно зростає. У цих умовах автор статті ставить за мету довести важливість розуміння істинних відносини між державою і Церквою, як вони вибудовувалися в минулому, особливо на місцях, як політика радянської влади впливала на сферу релігійного життя українства, у тому числі й на сферу монастирів Київської єпархії. Нинішнє формування української державності стоїть перед необхідністю виробити свою нову модель відносин із релігійними організаціями. Для цього варто об'єктивно і повною мірою вивчити економічні, політичні і соціальнокультурні аспекти історичного розвитку монастирів Київської єпархії, особливо її радянського періоду.

Феномен монастирів і ченців став багатоаспектним і давно вийшов за рамки релігійної свідомості та релігійного культу. Монастирі давно набули, окрім головного свого покликання - центру молитви і духовності, статусу освітніх і культурних осередків, стали зразковими для свого часу господарськими одиницями, фортецями, в'язницями тощо. Українські монастирі завжди були виразниками національної культури та самобутності. Їх історія тісно переплітається з вітчизняною історією, особливо трагічною у XX ст. Відродження цих інституцій у незалежній Україні сприймається як відродження національної ідентичності і національних цінностей, як ознака морального очищення суспільства, антитеза бездуховності та гонитві за матеріальним благополуччям. Значення монастирів сьогодні досить вагоме і виходить далеко за рамки «задоволення релігійних потреб окремих членів суспільства». Сучасні православні монастирі в Україні перетворилися на центри паломництва і туризму, вони не обділені увагою сучасних політиків та діячів культури.

Слово «монах» грецького походження і в перекладі означає «один», «одинокий». Цим підкреслюється віддалення ченців від мирського життя. До східних слов'ян чернецтво прийшло разом із Хрещенням Київської Русі. Перші київські монастирі були грецькими. Перша давньоруська школа чернецтва з'явилася із заснуванням преподобним Антонієм Києво-Печерської лаври у 1051 р. У процесі подальшого історичного розвитку діяльність монастирів органічно поєднувалася з політичним, соціальним, культурним та науковим життям певного регіону України.

На початку XX ст. монастирі Київської єпархії були взірцями ефективного ведення сільського господарства, упровадження передових методів агротехніки, раціональної організації тваринництва, тривалого зберігання продукції тощо [1, с. 16]. Вони виконували і значну соціокультурну місію. До 1917 р. православні монастирі Київщини займалися проповідництвом, організацією паломництва, хресних ходів, іконописом, поширенням релігійної літератури, освіти, виховання. Обителі перетворилися на потужні релігійно-культурні центри. Тут розташовувалися майстерні та бібліотеки. Часто монастирі своїм коштом утримували школи, училища, притулки та госпіталі. Урядовими установами Російської імперії не регулювалося ні число, ні вік, ні станова приналежність ченців.

Вони були переважно однорідними за своїм соціальним складом. У монастирях створювалася місцева система самоуправління, особлива організація - співдружність ченців, де цінувалися терпіння, працьовитість, відповідальність, високі моральні якості. Зовнішній нагляд за монастирями здійснював благочинний єпархії, обрання якого дозволялося на розсуд єпархіального архієрея. Посада благочинного була відповідальною, він особливо прискіпливо контролював моральний клімат в общинах і монастирях. Усі інші насельники монастиря - ченці, послушники і люди, що тимчасово перебували в стінах обителі - становили їі братію. Кожний із них повинен був підпорядковуватися церковному статуту і статуту свого монастиря, дотримуватися чернечої дисципліни.

Історія кожного монастиря була різною, але їхня доля у XX ст. стала однією для всіх. Із установленням радянської влади було скасовано церковно-адміністративну структуру. Декретом 1918 р. припинялася діяльність культових споруд і організацій, що існували при державних установах та відомствах, у школах і армії, скасовувалася релігійна присяга й обов'язковість церковних постанов для громадян. Цим завершилося відокремлення Церкви від держави [2, с. 18].

У 1918 р. більшовицьким державним керівництвом була започаткована кампанія 3 масового закриття монастирів та ліквідація їхнього майна. Монастирі і церковні общини позбавлялися права власності та статусу юридичної особи. Основний удар по православних монастирях був нанесений iз 1918 по 1921 р. До кінця 1930-х років процес закриття православних монастирів не припинявся. На початок 1940-х років в Україні фактично не залишилося жодного чинного монастиря. [3, с. 137]. Діяльність чернечих общин була спрямована у цей час на пошук можливих шляхів, які б забезпечили їх фізичне існування у соціалістичній державі. Монастирі пристосувалися до тих умов, які їм нав'язувала держава. Однією з нових форм збереження православних монастирських общин стали трудові кооперативи, що створювалися на базі їхніх господарств, - комуни або артілі. Тільки оголошенням 
себе трудовими комунами й артілями монахи могли зупинити розграбування монастиря селянами чи неконтрольовані реквізиції різними відомствами і військовими [4, с. 55].

Окрім того, Конституція РСФРР 1918 р., яка була поширена більшовиками і в Україні, позбавляла ченців виборчого права і забороняла їм бути членами комун та артілей. Із цього моменту місцеві ради повинні були взяти на облік усі монастирські господарства. Складовою частиною політики стала заборона релігійним організаціям здійснення благодійності, оскільки, на думку більшовицького керівництва, це сприяло перетіканню грошових засобів і майна громадян до служителів культу в обхід державної системи розподілу [5, ст. 607]. Однак тогочасне аграрне законодавство дозволяло збереження земельних угідь за монастирськими господарствами до 1920 р. Склад новоутворених артілей для обробки націоналізованої землі не обмежувався віросповіданням, статтю чи національністю, що створило можливості організації релігійних господарств на базі колишніх монастирів. У таких мовах єдиною можливістю для православних монастирів зберегтися було отримання статусу кооперативу, артілі тощо [6].

Упродовж 1920-1930-х років місцева влада такі артілі закривала. Мотивацією для їх ліквідації виголошувалося таке: вище партійно-радянське керівництво селянське колективне господарство вважало справді радянським, а чернечі артілі сприймалися ними як осередки контрреволюції. Як зазначала Е. Слободянюк, попри спробу центральної влади надати закриттю монастирів більш-менш цивілізованих форм більшість із них на місцях ліквідовували грубим адміністративним шляхом, без урахування інтересів чернецтва і громадської думки. Навіть офіційна статистика визнавала, що з 31 монастиря, закритого в Україні у 1924 р., тільки один був ліквідований за «побажаннями населення» [7, с. 105].

Зазвичай для ліквідації монастирів використовували найбільш традиційне формулювання, мовляв, релігійна община віруючих допускала в храмах, що йй належали, політичні зібрання і поширення контрреволюційної літератури, спрямованої проти радянської влади. Відповідно, такі доводи не залишалися без уваги з боку радянських правоохоронних органів.

Наступ на святі мощі був безпосередньо пов'язаний із процесом закриття і націоналізації православних монастирів, де вони у переважній своїй більшості й знаходилися. 14 лютого 1919 р. Наркоматом юстиції було видано постанову про організацію відкриття мощів у рамках кампанії з посилення антирелігійної пропаганди. Закриття монастирів і виселення чернецтва - це тільки перший етап нищення монастирів. Трагічною виглядає подальша доля монастирських будівель. Влада або відразу перетворювала чудові архітектурні споруди на звалище каміння, або прирікала їх на повільне руйнування. На кінець 1920-х років більшість монастирів України було перепрофільовано і передано під сільгоспартілі, колонії для безпритульних дітей. Деякі використовувалися як медичні та навчальні заклади, місця дислокації військових частин тощо.

Цікавими є дані, подані у дослідженні Ю. Мариновського, який указує на кількість та діяльність монастирів на Черкащині. Станом на 1 січня 1917 р. у тодішніх повітах Київської і Полтавської губерній офіційно функціонували 15 православних монастирів: Корсунський Онуфріївський жіночий, Ірдинський (Виноградський) Успенський чоловічий, Мошногірський Вознесенський чоловічий, Мотронинський Троїцький жіночий, Жаботинський Онуфріївський чоловічий, Медведівський Миколаївський чоловічий, Чигиринський Троїцький жіночий, Лебединський Миколаївський жіночий, Золотоніський Красногірський Іоанно-Богословський жіночий, Черкаський Покровський жіночий, Змагайлівський Успенський чоловічий, Лукашівський (Іванівський) Троїцький жіночий, Тальянський Миколаївський чоловічий, Кочержинський Георгіївський чоловічий, Уманський «Божої Матері Несподівана Радість» чоловічий [8, с. 19].

Станом на 1921 р. у місті Києві існувало сім чоловічих (Братський, Видубицький Михайлівський, ГрекоСинайський Свято-Катериненський, Києво-Печерська Успенська лавра, Михайлівський, Миколаївський, Свято-Троїцький) та три жіночих (Введенський, Покровський, Флорівський) монастирі [3, с. 139]. У межах Київської округи існувало два чоловічих (Різдва-Богородиці (на Церковщині), Свято-Пантелеімонівський (Феофанія)) та два жіночих (Ржищевсько-Спасо-Преображенський (м. Ржищів), Межигірський Спасо-Преображенський приписаний до Київського Покровського монастиря (Межигір'я)) монастирі. Обов'язки благочинного монастирів м. Києва та округи виконував архімандрит Давид [9, арк. 1-1 зв.].

Циркуляр Ліквідаційного відділу Наркомату юстиції від 21 червня 1921 р. мав на меті за допомогою губернських відділів управління зібрати точні свідчення про монастирі в межах губерній [3, с. 139]. Насамперед їх цікавило кількість чоловічих та жіночих монастирів окремо, кількість у кожному монастирі насельників (ченців та черниць) із поділом їх за віковими групами та соціальним станом. Особливий інтерес викликало матеріальне становище монастирів: наявність землі, рухомого та нерухомого майна [10, арк. 10].

Згідно з чинним законодавством, до 1922 р. майже в усіх монастирях Київської єпархії були утворені релігійні громади. У деяких обителях почали функціонувати сільськогосподарські артілі або трудові 
комуни, які складалися 3 монастирських насельників, монастирських робітників і служниць, що перебували у цих монастирях [8, с. 36].

Із кінця 1922 р. починається заключний етап в остаточному знищенні монастирів єпархії [3, с. 140]. Бюлетень НКВС України від 9 лютого 1923 р. подавав основні засади у ставленні до монастирів: «Закриття монастирів. 1. Міські і приміські монастирі, як чоловічі, так і жіночі, за загальним для всіх правилом повинні бути закриті. 2. У губерніях дозволяється залишити по одному чоловічому та одному жіночому монастирю, подалі від міст і залізниць. 3. Приміщення монастирів, що підлягають закриттю, повинні використовуватися для потреб соціального забезпечення, народної освіти, охорони здоров’я тощо. 4. Ченці і черниці похилого віку повинні бути переведеними до установ Собезу, якщо вони від цього не відмовляться і не побажають поїхати на батьківщину. 5. Організацію трудових артілей можна дозволяти лише на загальних засадах із колишніх послушників і послушниць» [8, с. 45].

Кількість монастирів чинних і зачинених та кількість ченців, що в них перебували, потрібно було визначати відповідно до адміністративно-територіального поділу 1923 р. на округи [3, с. 140]. Так, у 1923 р. Флорівський жіночий монастир був закритий радянською владою, а храм був переданий приходській общині. Черниці та послушниці звернулися із заявами до Президії ВУЦВК із проханням не виселяти їх із приміщень монастиря. Вони працювали і жили тут лише на засоби для існування, які отримували від копіткої роботи, - шиття. Це для них було єдине джерело доходу. Окрім того, у монастирі мешкали ще й черниці похилого непрацездатного віку. Один із корпусів монастиря був заселений більше ніж 50 інвалідами. Деякі з них були прикутими до ліжка [11, арк. 16].

На території Київської єпархії у 1925 р. продовжували існувати релігійні громади, що функціонували при ще офіційно не закритих монастирях: Іванівському (Лукашівському), Лебединському, Мотронинському жіночих і Медведівському, Мошногірському, Тальянському, Уманському і Кочержинському [3, с. 140]. Серед монастирів Черкаської округи найбільшим був Лебединський жіночий монастир, у якому мешкали близько 350 черниць. На початку 1926 р. у Білоцерківській окрузі, в місті Богуславі, існував Миколаївський жіночий монастир. На його території було два молитовних будинки та сім монастирських житлових будинків, якими користувалася трудова артіль «Колос». До ії складу входили 149 черниць, які мешкали в будинках монастиря, зареєстрована релігійна громада, яка налічувала 78 осіб без урахування ченців [12, арк. 40].

У Бердичівській окрузі нараховувалось три монастирі: у с. Скаржинці Уланівського району - Миколаївський чоловічий монастир, де несли послух вісім ченців та чотири послушники; у м. Любар Любарського району - жіночий монастир, який мав дві будівлі, один храм, де звершував богослужіння один священик. Усі інші будівлі знаходилися у розпорядженні дитячого містечка, де мешкала 351 особа (діти та персонал). Двоє черниць жили на території монастиря, а 34 черниці мандрували у межах округи [3, с. 141]. Монастир був ліквідований у 1925 р. Ще один жіночий монастир був розташований у Чуднові, там перебували 180 черниць та два священики, що звершували богослужіння [12, арк. 55].

В Уманській окрузі налічувалося два монастирі. Георгіївський чоловічий монастир у с. Кочержинці Уманського району мав один молитовний будинок, де несли свій послух 26 ченців та шість черниць. Релігійна громада була зареєстрована та налічувала 237 осіб без урахування ченців. У с. Тальянки Бабанського району був розташований Миколаївський Києво-Троїцький монастир, ймовірно, скит одного $з$ монастирів Києва. На території монастиря був один молитовний будинок, релігійна громада не зареєстрована, тому садибами користувалася аграрна школа. При монастирі несли послух 50 ченців та одна черниця [12, арк. 65].

Поза увагою не залишилася й Києво-Печерська лавра, яка на той час мала 17 будівель та 315 осіб - членів релігійної громади. За статистичними підрахунками, у межах Київської округи мандрувало 800 ченців та 350 черниць у пошуках засобів існування та молитовного притулку [12, арк. 74]. Згідно з Постановою ВУЦВК та РНК УСРР від 29 вересня 1926 р., Києво-Печерську лавру було оголошено Всеукраїнським державним культурно-історичним заповідником із перетворенням його у Всеукраїнське музейне містечко [13, арк. 9]. Згідно з проханням Президії Київської міськради від 7 жовтня 1929 р. № 19 про закриття молитовних приміщень на терені монастирів: Києво-Печерського, Флорівського, Іонівського, Покровського, Китаєвського та Преображенського в м. Києві та виселення ченців із приміщень цих монастирів, вищеназвані приміщення монастирів були закриті та використовувалися для культурних потреб, а ченців виселено [13, арк. 3].

Проведення богослужінь за участю архієреїв як у простих приходських храмах, так і в монастирях дозволялося лише зі згоди Окрліквідкому. Про це свідчить лист общини Лебединського жіночого монастиря, яка просить Черкаський окрліквідком дозволити запросити єпископа Філарета (Лінчевського) для проведення богослужіння 7-8 червня 1924 р. [13, арк. 101]. 
Згідно з Постановою Шевченківського ОВК від 27 березня 1924 р. «Про заборону проведення релігійних ходів на вулицях та площах без дозволу Окрліквідкому», заборона хресних ходів, будь-яких релігійних ходів та обрядів, які звершувалися поза приміщенням храму, а саме на вулиці міста чи села, також заборонялися [14, арк. 54]. Для цього теж потрібно було отримати спеціальний дозвіл, якому передувало декілька зобов'язань, які мав виконати священик або група віруючих. Задля одержання дозволів на проведення хресного ходу заздалегідь, не пізніше як за 24 години до його початку, потрібно було подати заяви до Окрліквідкому, які повинні бути оплаченими гербовим збором у сумі одного червоного карбованця. Особи, які не дотрималися таких зобов'язань, притягувалися до кримінальної відповідальності [14, арк. 66 зв.].

Всеукраїнська антирелігійна комісія при агітаційно-пропагандистському відділі ЦК КП(б)У визначала порядок здійснення хресних ходів. Уважалося неприпустимим запрошувати священнослужителів з інших приходів. Хресний хід міг відбутися в загальному порядку, встановленому Наркоматом внутрішніх справ. Служителі культу, які не дотримувалися цього, притягувалися до суворої відповідальності [15, арк. 22].

24 січня 1934 р. ХІІ з'їзд Комуністичної партії України та ВУЦВК ухвалили перенести столицю УСРР з Харкова до Києва. Терміново розпочинається «соціалістична реконструкція» міста, під час якої було знищено більше половини давніх пам'яток. Місто, де була велика кількість церков і монастирів, повинне було перетворитися на архітектурний центр соціалістичної радянської України. [3, с. 143]. На місці Михайлівського Золотоверхого монастиря та стародавньої Трьохсвятительської церкви було заплановано створити урядовий центр із величезною парадною площею. Хоча місце було для цього дуже незручним, але його вибрано з ідеологічних міркувань. Уповноважений Й. Сталіна в Україні П. Постишев заявив, що його завдання - знищити центр української контрреволюції. Отже, проєктований урядовий центр був лише приводом для свідомого руйнування стародавніх пам'яток, тому й не дивно, що на місці Михайлівського собору так нічого і не було зведено [16, с. 141].

Отже, у 1920-1930-х роках життя монастирів та доля їхніх насельників кардинально змінилися. Заходи радянської держави, що виражалися у конфіскації церковних цінностей, реорганізації та закритті монастирів і храмів, відображали політику радянської держави у царині духовної культури того часу. На долю монастирів Київської єпархії випали вкрай важкі випробування. У період 1919-1921 рр. закриття монастирів набуло особливо масового характеру. Незважаючи на те що вони були важливими осередками церковно-релігійного, науково-освітнього та культурно-мистецького життя, все ж таки потрапили під приціл влади як об'єкти, які мали матеріальну цінність, про що свідчать факти націоналізації їх майна, вилучення цінностей зі столичних обителей та в округах, позбавлення їх права володіти і користуватися землею. Настоятелі монастирів шукали способи зберегти монастирський уклад. Необхідність налагодження церковного життя в нових умовах змусила Православну церкву шукати нові форми існування своїх інститутів. Однак радянська влада знайшла способи і методи, за допомогою яких було закрито монастирі і ліквідовано чернецтво як особливу соціальну групу людей в Україні.

\section{Література:}

1. Слободянюк Е.П. Православ'я в Україні у 20-х - середині 30-х років XX ст. : автореф. дис. ... канд. іст. наук : 07.00.01. Львів, 1996. 20 с.

2. Собрание узаконений и распоряжений рабочего и крестьянского правительства РСФСР. Москва, 1917. № 2. Ст. 18.

3. Чучалін О.П. Київська єпархія в умовах взаємин радянської держави і Православної церкви : дис. ... канд. іст. наук : 07.00.01 ; Чорноморський національний університет імені Петра Могили. Миколаїв, 2018. 266 с.

4. Редькина О.Ю. Сельскохозяйственные религиозные трудовые коллективы в 1917-1930-е гг.: на материалах европейской части РСФСР. Волгоград, 2004. 186 с.

5. Собрание узаконений и распоряжений рабочего и крестьянского правительства РСФСР. Москва, 1918. № 51 . Ст. 607.

6. Васильев Александр, протоиерей. Попытки сохранения православных монастырей в первые годы советской власти (1917-1920-e). URL: http:/history-mda.ru/ akoluf@yandex.ru date:2020-12-21.

7. Слободянюк Е. Монастирі України: історія нищення. Київська старовина. 1995. № 1. С. 105-108.

8. Мариновський Ю.Ю. Черкаська минувшина. Книга II. Православні монастирі на терені сучасної Черкаської області після 1917 року. Черкаси : Відлуння-Плюс, 2002. 480 с.

9. Державний архів Київської області. Ф. Р-862. Оп. 1. Спр. 219.7 арк.

10. Центральний державний архів вищих органів влади і управління України (далі - ЦДАВО України). Ф. 8. Оп. 1. Спр. 768. 18 арк.

11. ЦДАВО України. Ф. 1. Оп. 7. Спр. 345. 53 арк.

12. ЦДАВО України. Ф.2. Оп. 2. Спр. 958.85 арк.

13. Державний архів Черкаської області (далі - ДАЧО). Ф. Р-345. Оп. 1. Спр. 73. 190 арк.

14. ДАЧО. Ф. Р-375. Оп. 1. Спр. 67. 226 арк.

15. Центральний державний архів громадських об'єднань України. Ф. 1. Оп. 20. Спр. 1842. 54 арк.

16. Дегтярьов М.Г. Михайлівський Золотоверхий монастир ; 2-е вид., стереотип. Київ : Техніка, 1999. 160 с. 